Published in "Archaeometry 52(1): 131-145, 2010"

which should be cited to refer to this work.

\title{
TOOLS TO QUALIFY EXPERIMENTS WITH BLOOMERY FURNACES*
}

\author{
M. SENN ${ }^{1} \dagger$, U. GFELLER ${ }^{2}$, B. GUÉNETTE-BECK ${ }^{3}$, \\ P. LIENEMANN ${ }^{2}$ and A. ULRICH ${ }^{1}$
${ }^{1}$ Empa, Swiss Federal Laboratories for Materials Testing and Research, Laboratory for Analytical Chemistry, Überlandstrasse 129, CH-8600 Dübendorf, Switzerland
${ }^{2}$ Empa, Laboratory for Solid State Chemistry and Catalysis, Überlandstrasse 129, CH-8600 Dübendorf, Switzerland
${ }^{3}$ Geosciences, University of Fribourg, CH-1700 Fribourg, Switzerland

\begin{abstract}
Five experimental bloomery iron ore smelts were carried out in a reconstruction of an early medieval furnace of the Boécourt type (Switzerland). A part of the bloom from the most successful experiment was forged to a billet. Starting materials and products were weighed, described and chemically characterized (ICP-MS, LA-ICP-MS and WD-XRF). The calculation of the yield and mass balance based on the chemical analyses from the ore (optimum) and from the ore, furnace lining, slag and ash (applied) allow the determination and quantification of the materials involved in the process. This permits the interpretation of the quality of the experiments. The chemical characterization of metal produced from hematite ore from the Gonzen Mountains in Switzerland gives archaeologists the possibility to compare the metal of iron artefacts to metal from this mine. Finally a good agreement between experiments and archaeological reality can be shown.
\end{abstract}

\section{KEYWORDS: EXPERIMENTAL ARCHAEOLOGY, EARLY MEDIEVAL TIMES, NORTHERN SLOPES OF THE SWISS ALPS, BLOOMERY SMELTING, HEMATITE ORE, WD-XRF, ICP-MS, LA-ICP-MS, YIELD AND MASS BALANCES}

\section{CONTEXT}

Experimentation combined with modern analytical techniques and calculations can help to verify the theory concerning direct iron reduction. The analytical techniques allow the interpretation of the products; while measurements carried out during experiments help to control the experimental process. A series of experiments was conducted studying the bloomery smelting of hematite ore from the Gonzen Mountains, Wolfslochstollen, Switzerland. The Gonzen Mountains contain a massive hematite-manganese ore deposit (Pfeifer et al. 1988). In this context only the hematite part of the ore is of interest. It contains iron oxide-dominated ore with hematite $\left(\mathrm{Fe}_{2} \mathrm{O}_{3}\right)$ and magnetite $\left(\mathrm{Fe}_{3} \mathrm{O}_{4}\right)$ besides variable amounts of quartz $\left(\mathrm{SiO}_{2}\right)$, ferroan calcite $\left((\mathrm{Ca}, \mathrm{Fe}, \mathrm{Mn}, \mathrm{Mg}) \mathrm{CO}_{3}\right)$ and some pyrite $\left(\mathrm{FeS}_{2}\right)$.

A group of Swiss archaeologists and smiths performed five iron-smelting experiments in a reconstructed bloomery furnace during a campaign lasting 10 days in 1998 (Senn et al. 2001). During and after the experiments combustion processes and all materials involved were analysed at Empa. In 2001, Paul Merluzzo from the 'Laboratoire d'archéologie des métaux' in Nancy, France, forged one of the blooms into a billet. Beginning in 2007 Empa at Dübendorf began 


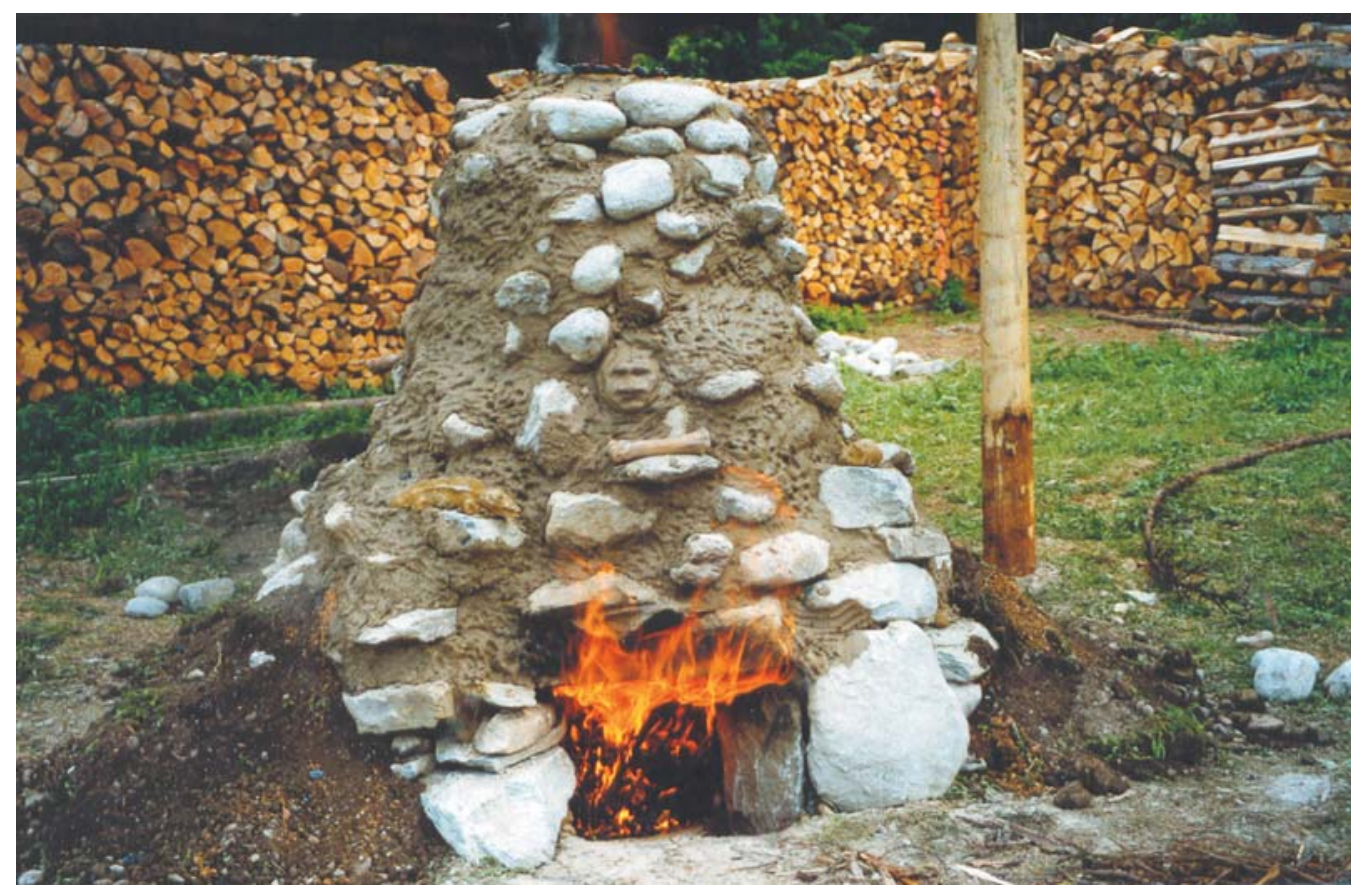

Figure 1 The experimental shaft furnace with a height about $2 \mathrm{~m}$.

to work in experimental archaeology and new smelting experiments were started. The aim of this new project is to produce highly accurate mass balances and to produce fluid slag which is freely tapped from the furnace.

\section{METHOD OF IRON ORE REDUCTION}

Bloomery furnaces have been used for the production of iron metal from the 10th century $\mathrm{BC}$ until the 20th century AD. In the bloomery or direct reduction process, only the slag undergoes liquefaction, whereas the iron remains solid. The metal produced has the form of a spongy bloom including slag and charcoal. Today iron is produced by indirect reduction in blast furnaces, a process that started in Europe in the 11th century AD.

An early medieval furnace from Boécourt, Switzerland was taken as a model for the experimental furnace (Eschenlohr and Serneels 1991). The experimental furnace had a bowl-shaped furnace chamber with internal dimensions of $0.8 \times 0.6 \times 0.6 \mathrm{~m}$, one lateral and one frontal tuyere in the door and a shaft (Fig. 1). The total height was $2 \mathrm{~m}$. Five consecutive runs were carried out in this furnace over 10 days. The air was supplied only through the lateral tuyere, never through the one in the front door. In the first and second experiments, bellows were used. For the other experiments an electric fan supplied the air. To start with, the ore was roasted in an open fire to make it easier to break into hazelnut-sized pieces. In the evening, the furnace was warmed using charcoal and natural draft. The next morning the furnace was refilled with charcoal and heating was assisted by blowing the additional air supply. Charging the furnace with ore started once the temperature had reached $900^{\circ} \mathrm{C}$. The charcoal to ore ratio used was 1:1. The first two charges were of $2 \mathrm{~kg}$, further additions were of $4 \mathrm{~kg}$, up a total of 
Table 1 Masses of raw materials used and products obtained

\begin{tabular}{|c|c|c|c|c|c|c|c|c|c|}
\hline \multirow[b]{3}{*}{ Experiment } & \multicolumn{5}{|c|}{ Consumption (kg) } & \multicolumn{4}{|c|}{ Products $(\mathrm{kg})$} \\
\hline & \multicolumn{4}{|c|}{ Charcoal } & \multirow{2}{*}{ Ore } & \multirow{2}{*}{ Metal } & \multicolumn{2}{|c|}{ Slag } & \multirow{2}{*}{ Total } \\
\hline & Preheating & Charging & Heating & Total & & & Tap slag & Furnace slag & \\
\hline EXP1 & 91 & 30 & 18 & 139 & 30 & 3 & 4.3 & 10.7 & 18 (incomplete) \\
\hline EXP2 & 43 & 30 & 18 & 91 & 30 & 1.5 & 3.1 & 17.4 & 22 (incomplete) \\
\hline EXP3 & 120 & 30 & 16 & 166 & 30 & 2.2 & 2.8 & 23 & 28 \\
\hline EXP4 & 58 & 30 & 20 & 108 & 30 & 2.2 & 6.2 & 14.6 & 23 \\
\hline EXP5 $^{a}$ & 77 & 30 & 16 & 123 & 30 & 4.4 & 7.7 & 12.9 & 25 \\
\hline
\end{tabular}

${ }^{a}$ Reduced iron from this experiment was used to smith a billet.

$60 \mathrm{~kg}$. After the end of the smelting process the furnace was opened and emptied the same evening or the following morning. In all the experiments, the ore was successfully smelted. The slag and bloom were found adhering to the lateral tuyere.

\section{MEASURING DURING THE EXPERIMENTS}

Temperatures, pressures and gas flows were recorded on-line using thermocouples, a manometer and a gas meter, a non-dispersive infra-red spectrometer and an oxygen sensor detection of paramagnetism. With this equipment it was possible to determine and control the following parameters:

- Temperature: ore charging was always started at temperatures of $900^{\circ} \mathrm{C}$; a highest temperature of $915^{\circ} \mathrm{C}$ was measured. The thermocouple was situated in the back of the furnace chamber. In consequence the actual maximum achieved temperature was likely to be higher than recorded.

- Pressure within the furnace: in most experiments there was a slight overpressure in the furnace chamber (10 to 70 Pascal) with the exception of the last experiment, which was performed with a slight underpressure.

- Calibration of the bellows (see example below).

- Gas composition in the furnace chamber: oxygen $\left(\mathrm{O}_{2}\right)$, carbon dioxide $\left(\mathrm{CO}_{2}\right)$.

During the second experiment about twice as much air was supplied as in Experiment 1, which resulted in measurable quantities of oxygen in the furnace chamber (Senn et al. 2001). The twofold increase of oxygen was sufficient to lower the amount of iron metal formed, as shown in Table 1: only $1.5 \mathrm{~kg}$ of iron metal was obtained in excess oxygen, whereas $3.0 \mathrm{~kg}$ were obtained with less oxygen. The volume of air delivered in these two experiments can be estimated from the calibration of the bellows. The bellows in Experiment 1 blew 185 litres air into the furnace in 10 strokes. The blowing rate was about 20 strokes/min. With this method, about 370 litres of air were blown into the furnace per minute, over the $9 \mathrm{~h}$ of the smelting time. In Experiment 2, bellows with a different tube introduced 193 litres of air in the furnace with 10 strokes. At a rhythm of 32 strokes/min, air was introduced over a smelting period of $10 \mathrm{~h}$. At this speed about 620 litres air per minute were blown into the furnace. That is about twice as much air introduced in the furnace as in Experiment 1. 

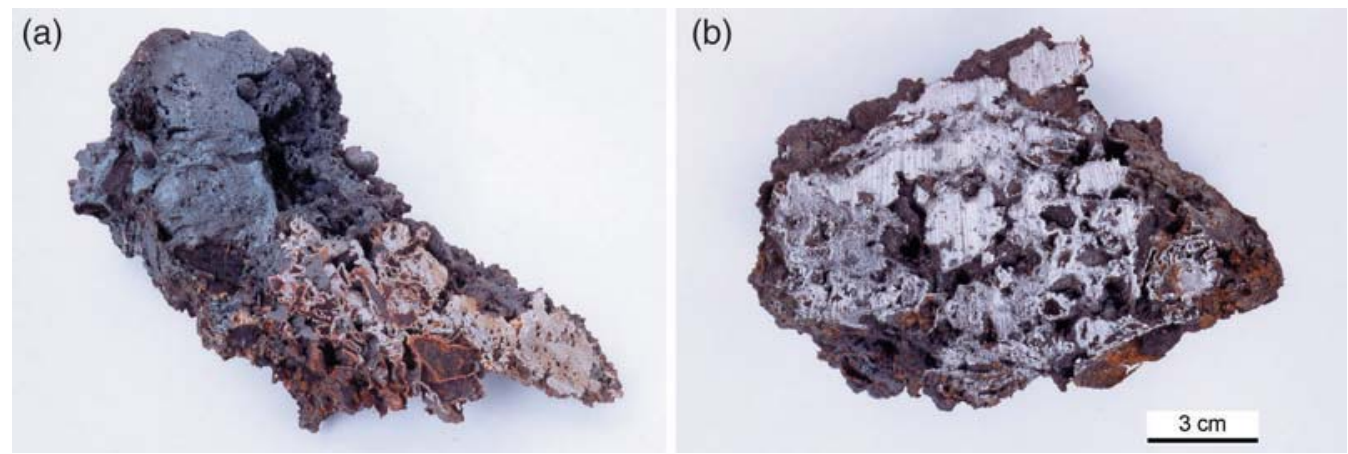

Figure 2 Two types of bloom: (a) slag with metal in the upper part (Experiment 1); (b) bloom separated from slag (Experiment 5).

\section{DESCRIPTION OF THE PRODUCTS OF THE EXPERIMENTS}

The quantities of raw materials used and of products formed during Experiments 1 to 5 are given in Table 1. The metal and slag accumulated around the lateral tuyere and the slag was also found adhering to the furnace wall. The slag did not run out of the furnace, but partially had a tapped appearance. Most of the slag had the form of dense furnace slag, the quantities of tap slag always being smaller (Table 1). The metal formed in the upper part of the furnace slag, as shown in Figure 2 (a). Only in Experiment 5 was the bloom separated from the slag (Fig. 2 (b)). The experiments of Crew showed that the separation of the bloom was caused by a special blowing technique with a high blowing rate (Crew and Charlton 2007). It is unknown if this was also the case in Experiment 5. The only recorded difference compared to the other experiments was the underpressure. The bloom obtained had a weight of $2.56 \mathrm{~kg}$ and contained more than half of the metal formed in Experiment 5; the rest of the metal remained adhering to the slag. The metallographic examination showed that it consisted of iron. Locally the surface was carburized to hypoeutectoid steel with a maximum about 0.4 mass $\%$ of carbon. The metal of the bloom had a high content of slag and charcoal inclusions (Fig. 2 (b)). Half of the bloom was forged (starting weight $1.3 \mathrm{~kg}$ of metal) by wrapping in clay and straw and was heated several times at white heat in the smithing hearth. Subsequently it was lightly hammered. This procedure compacted and consolidated the bloom. The forging work was stopped when two raw billets (Fig. 3) were formed, enclosing a considerable amount of slag inclusions and porosity (Fig. 4). A billet is a bloom hammered to a compact sub-rectangular block (Crew 1994). The two parts of forged metal weighed only $0.37 \mathrm{~kg}$. The iron loss while refining the metal was about $70 \%$. Additionally, a plano-convex smithing slag (weight $0.81 \mathrm{~kg}$ ) with a big metal inclusion (Fig. 5) was formed in the smithing hearth. The metal inclusion makes this slag very similar to the early medieval bloom forging slag found in DevelierCourtételle, Switzerland (Eschenlohr et al. 2007).

\section{OPTIMUM YIELD AND MASS BALANCE DEDUCED FROM THE CHEMICAL ANALYSES OF THE ORE}

The amount of iron produced varied from 1.5 to $4.4 \mathrm{~kg}$, with the highest yields in the first and last experiments. But were these good experiments with respect to product quality and product yield? Chemical analyses of materials involved and deduced yields and mass balances will give an answer. 


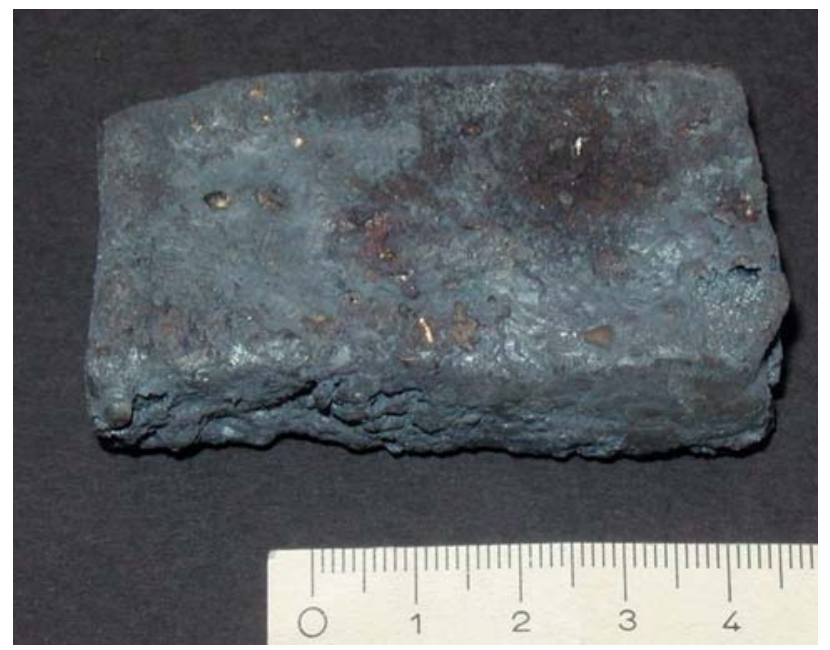

Figure 3 One of the two forged billets.

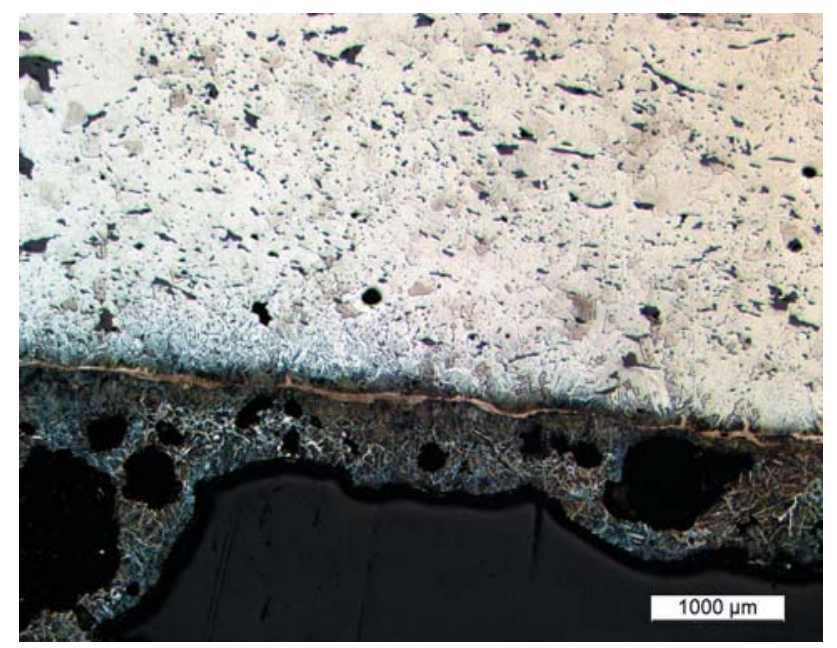

Figure 4 Micrograph of the billet: iron (white) with slag inclusions and porosity (black inclusions), the surface below (dark) is strongly cemented and burnt.

The ore, furnace lining and slag were analysed by wavelength-dispersive X-ray fluorescence (WD-XRF). From each sample $50 \mathrm{~g}$ of material was cut and milled to powder in an agate stone mortar. Analyses are carried out on powder and fused glass tablets. A part of the powder was used to determine certain trace elements $(\mathrm{V}, \mathrm{Cr}, \mathrm{Co}, \mathrm{Ni}, \mathrm{Cu}, \mathrm{As})$ in the ore with inductively coupled plasma mass spectrometry (ICP-MS). The powder was solved in aqua regia; calibration was made with a multi-element solution and rhodium as internal standard material. The metal of blooms and billets were analysed by metallography and laser ablation coupled with inductively coupled plasma mass spectrometry (LA-ICP-MS). Sample preparation and method are 


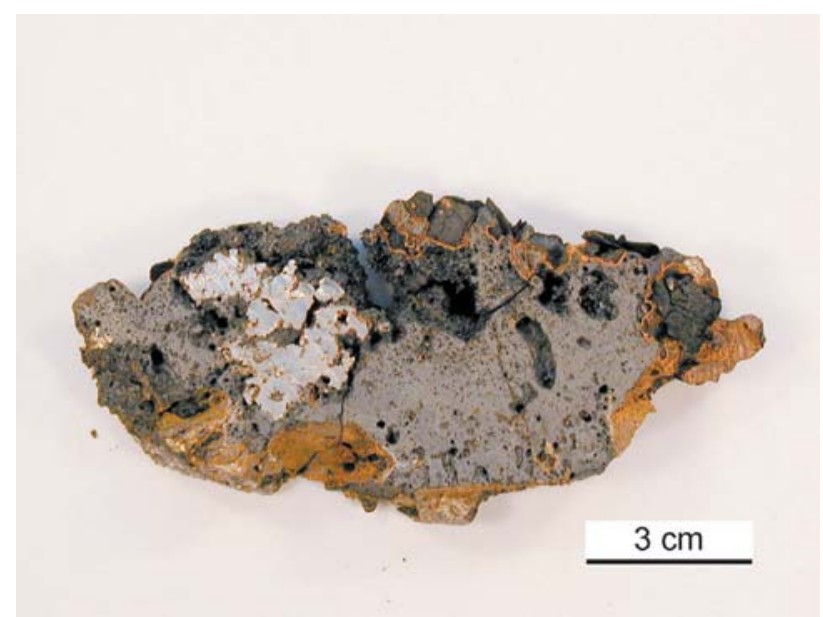

Figure 5 Cut through the plano-convex hearth-bottom slag with the big metal inclusion formed while forging the billet.

described in Devos et al. (2000). Each result, expressed as a median, is based on a minimum of five single analyses.

From the chemical compositions of the ore the yield can be calculated. Because roasted ore was used in experimentation, all calculations are based on the mean iron content of $56 \%$ in the roasted ore (see Table 2). Experimental yields of the bloomery smelting were calculated by dividing the amount of iron produced by the amount of iron in $30 \mathrm{~kg}$ of roasted ore $(16.8 \mathrm{~kg}$ of iron). Thus, the experimental yield varied between 9 and $26 \%$.

In a second step the optimum yield for the bloomery process was calculated. In the direct reduction process a substantial amount of the iron in the ore is consumed in slag formation. This is explained by the assumption that for ores with low calcium content a slag can be described as a mixture of fayalite $\left(\mathrm{Fe}_{2} \mathrm{SiO}_{4}\right)$, hercynite $\left(\mathrm{FeAl}_{2} \mathrm{O}_{4}\right)$ and a glassy matrix. The optimum yield for the direct reduction is calculated according to the formula:

\section{[(Amount of iron in $30 \mathrm{~kg}$ ore - amount of iron bound in slag) / amount of iron in $30 \mathrm{~kg}$ of ore $\times 100=$ yield}

According to this formula, resolved by a molar calculation, from the amount of $16.8 \mathrm{~kg}$ iron in the roasted ore about $5.7 \mathrm{~kg}$ of iron is consumed to form the slag, while $11.1 \mathrm{~kg}$ metal is reduced from the ore. This corresponds to a yield of $66 \%$ and is the optimum yield for a bloomery smelt. However, this does not take into consideration the fact that a third mineral, wustite $(\mathrm{FeO})$, can also crystallize in bloomery reduction slag. As it is not possible to predict how much iron in the ore will be reduced to wustite (FeO), it can only be said that the effective yield is expected to be below $66 \%$.

\section{APPLIED YIELD AND MASS BALANCES BASED ON CHEMICAL COMPOSITION OF ALL MATERIALS}

Further calculations according to Eschenlohr and Serneels (1991) were performed based on the chemical composition of ore, slag, ash and furnace lining to find a more accurate mass balance and yield. They will clarify how well the optimum yield and the practical results of 
Table 2 The chemical composition of hematite ore, experimental slag and furnace lining (analysed by WD-XRF) expressed in g/100 $\mathrm{g}$ (mass \%)

\begin{tabular}{|c|c|c|c|c|c|c|c|c|c|c|c|c|c|c|c|c|c|c|}
\hline \multirow{2}{*}{ Context } & \multirow{2}{*}{ Material } & \multicolumn{3}{|c|}{ Main components } & \multirow[b]{2}{*}{$\mathrm{Fe}_{2} \mathrm{O}_{3}$} & \multirow[b]{2}{*}{$\mathrm{MnO}$} & \multirow[b]{2}{*}{$\mathrm{MgO}$} & \multirow[b]{2}{*}{$\mathrm{CaO}$} & \multirow[b]{2}{*}{$\mathrm{K}_{2} \mathrm{O}$} & \multirow[b]{2}{*}{$\mathrm{P}_{2} \mathrm{O}_{5}$} & \multirow[b]{2}{*}{$\mathrm{SO}_{3}$} & \multicolumn{3}{|c|}{ Trace elements } & \multicolumn{3}{|c|}{ Main elements ${ }^{1}$} & \multirow{2}{*}{$\begin{array}{c}\text { Ratio } \\
\text { Si/Al }\end{array}$} \\
\hline & & $\mathrm{SiO}_{2}$ & $\mathrm{TiO}_{2}$ & $\mathrm{Al}_{2} \mathrm{O}_{3}$ & & & & & & & & $S r$ & $B a$ & $V$ & $\mathrm{Fe}$ & Si & $A l$ & \\
\hline \multirow[t]{5}{*}{ Ore } & Unroasted ore, mean $(n=9)$ & 7.6 & 0.04 & 1.0 & 70 & 3.4 & 0.60 & 7.9 & 0.03 & 0.06 & 0.15 & 0.04 & 0.26 & 0.008 & 54 & 3.9 & 0.58 & 7.1 \\
\hline & S.D. & 2.7 & 0.01 & 0.20 & 13 & 4.4 & 0.20 & 4.0 & 0.01 & 0.02 & 0.06 & 0.03 & 0.15 & 0.003 & 7.8 & 1.4 & 0.12 & 2.9 \\
\hline & Roasted ore, GON-C & 6.4 & 0.05 & 0.99 & 77 & 3.8 & 1.0 & 9.2 & $<$ & 0.07 & 0.64 & 0.04 & 0.37 & 0.009 & 54 & 3.0 & 0.53 & 5.7 \\
\hline & Roasted ore, mean $(n=3)$ & 10 & 0.04 & 0.82 & 80 & 1.3 & 0.51 & 6.0 & 0.02 & 0.09 & 0.45 & 0.02 & 0.20 & 0.007 & 56 & 4.8 & 0.43 & 12 \\
\hline & S.D. & 3.4 & 0.02 & 0.20 & 3.0 & 2.2 & 0.40 & 3.0 & 0.01 & 0.02 & 0.18 & 0.02 & 0.14 & 0.002 & 2.2 & 1.6 & 0.11 & 7.1 \\
\hline \multirow[t]{4}{*}{ Experiment 1} & Tap slag & 23 & 0.46 & 8.7 & 55 & 2.6 & 1.0 & 7.6 & 0.78 & 0.19 & $<$ & 0.04 & 0.16 & 0.013 & 39 & 11 & 4.6 & 2.3 \\
\hline & Tap slag & 27 & 0.52 & 9.9 & 49 & 2.6 & 1.4 & 7.8 & 0.83 & 0.18 & 0.01 & 0.03 & 0.11 & 0.015 & 35 & 13 & 5.3 & 2.4 \\
\hline & Furnace slag & 14 & 0.25 & 4.4 & 70 & 2.1 & 1.0 & 7.2 & 0.45 & 0.12 & $<$ & 0.03 & 0.10 & 0.013 & 49 & 6.7 & 2.3 & 2.9 \\
\hline & Furnace slag & 10 & 0.21 & 3.7 & 78 & 1.4 & 0.65 & 4.3 & 0.33 & 0.05 & $<$ & 0.02 & 0.11 & 0.012 & 55 & 4.9 & 2.0 & 2.5 \\
\hline \multirow[t]{7}{*}{ Experiment 2} & Tap slag & 19 & 0.33 & 6.5 & 62 & 2.3 & 1.1 & 6.8 & 0.68 & 0.21 & 0.02 & 0.03 & 0.11 & 0.012 & 44 & 9.1 & 3.5 & 2.6 \\
\hline & Tap slag & 24 & 0.45 & 8.3 & 53 & 2.7 & 1.4 & 8.0 & 0.76 & 0.15 & 0.02 & 0.04 & 0.12 & 0.010 & 37 & 11 & 4.4 & 2.6 \\
\hline & Furnace slag & 15 & 0.30 & 5.0 & 69 & 2.6 & 0.94 & 6.4 & 0.62 & 0.18 & $<$ & 0.03 & 0.13 & 0.012 & 48 & 7.0 & 2.7 & 2.6 \\
\hline & Furnace slag & 18 & 0.46 & 8.6 & 64 & 2.1 & 0.67 & 5.3 & 0.45 & 0.10 & $<$ & 0.03 & 0.12 & 0.018 & 45 & 8.3 & 4.6 & 1.8 \\
\hline & Furnace lining & 42 & 1.3 & 24 & 25 & 1.2 & 0.75 & 3.3 & 1.4 & 0.12 & $<$ & 0.01 & 0.06 & 0.029 & 18 & 20 & 13 & 1.5 \\
\hline & Furnace lining & 42 & 1.3 & 24 & 26 & 1.3 & 0.65 & 2.9 & 0.68 & 0.12 & $<$ & 0.02 & $<$ & 0.029 & 18 & 20 & 13 & 1.6 \\
\hline & Furnace lining, mean $(\mathrm{n}=2)$ & 42 & 1.3 & 24 & 26 & 1.3 & 0.70 & 3.1 & 1.0 & 0.12 & & 0.02 & 0.06 & 0.029 & 18 & 20 & 13 & 1.6 \\
\hline \multirow[t]{2}{*}{ Slag Exp. 1 and 2} & Tap slag, mean $(n=4)$ & 23 & 0.40 & 8.4 & 55 & 2.6 & 1.2 & 7.6 & 0.76 & 0.18 & 0.02 & 0.04 & 0.13 & 0.013 & 39 & 11 & 4.4 & 2.5 \\
\hline & Furnace slag, mean $(n=4)$ & 14 & 0.31 & 5.4 & 70 & 2.1 & 0.82 & 5.8 & 0.46 & 0.11 & $<$ & 0.03 & 0.12 & 0.014 & 49 & 6.7 & 2.9 & 2.3 \\
\hline \multirow[t]{4}{*}{ Experiment 3} & Tap slag & 29 & 0.23 & 5.3 & 49 & 0.93 & 2.6 & 11 & 1.4 & 0.30 & 0.02 & 0.03 & 0.11 & 0.016 & 34 & 14 & 2.8 & 4.9 \\
\hline & Tap slag & 26 & 0.20 & 4.6 & 54 & 1.2 & 2.2 & 9.7 & 1.2 & 0.20 & $<$ & 0.04 & 0.10 & 0.015 & 38 & 12 & 2.5 & 5.0 \\
\hline & Furnace slag & 14 & 0.12 & 2.3 & 72 & 1.4 & 1.3 & 7.3 & 0.63 & 0.16 & $<$ & 0.03 & 0.09 & 0.009 & 51 & 6.5 & 1.2 & 5.3 \\
\hline & Furnace slag & 7.9 & 0.09 & 1.4 & 83 & 1.2 & 0.98 & 4.9 & 0.30 & 0.08 & $<$ & 0.02 & 0.09 & 0.015 & 58 & 3.7 & 0.74 & 5.0 \\
\hline \multirow[t]{4}{*}{ Experiment 4} & Tap slag & 30 & 0.44 & 9.0 & 48 & 0.70 & 1.9 & 8.0 & 1.1 & 0.17 & $<$ & 0.03 & 0.06 & 0.013 & 34 & 14 & 4.8 & 2.9 \\
\hline & Tap slag & 30 & 0.41 & 8.4 & 48 & 0.72 & 2.0 & 8.1 & 1.2 & 0.17 & $<$ & 0.03 & 0.09 & 0.001 & 34 & 14 & 4.5 & 3.2 \\
\hline & Furnace slag & 19 & 0.24 & 4.9 & 65 & 0.92 & 1.2 & 6.6 & 0.63 & 0.17 & 0.01 & 0.03 & 0.15 & $<$ & 46 & 9.1 & 2.6 & 3.5 \\
\hline & Furnace slag & 20 & 0.30 & 5.4 & 62 & 2.1 & 1.4 & 7.2 & 0.70 & 0.12 & $<$ & 0.03 & 0.11 & 0.012 & 44 & 9.4 & 2.9 & 3.3 \\
\hline \multirow[t]{5}{*}{ Experiment 5} & Tap slag & 27 & 0.37 & 7.7 & 50 & 2.2 & 1.7 & 9.0 & 0.93 & 0.18 & $<$ & 0.04 & 0.13 & 0.011 & 35 & 13 & 4.1 & 3.1 \\
\hline & Tap slag & 26 & 0.35 & 7.1 & 52 & 2.2 & 1.6 & 8.9 & 0.89 & 0.20 & $<$ & 0.03 & 0.11 & 0.010 & 37 & 12 & 3.8 & 3.2 \\
\hline & Furnace slag & 29 & 0.28 & 6.1 & 48 & 1.6 & 2.3 & 10.3 & 1.3 & 0.25 & $<$ & 0.03 & 0.12 & 0.007 & 34 & 14 & 3.3 & 4.2 \\
\hline & Furnace slag & 28 & 0.26 & 5.9 & 50 & 1.8 & 2.3 & 9.6 & 1.1 & 0.19 & 0.02 & 0.03 & 0.11 & 0.011 & 35 & 13 & 3.1 & 4.1 \\
\hline & Furnace lining & 45 & 0.38 & 8.4 & 26 & 1.1 & 3.9 & 11.7 & 2.1 & 0.23 & $<$ & 0.03 & 0.07 & 0.012 & 18 & 21 & 4.5 & 4.8 \\
\hline \multirow[t]{2}{*}{ Slag Exp.1-5 } & Furnace slag, mean $(\mathrm{n}=10)$ & 17 & 0.25 & 4.8 & 66 & 1.7 & 1.3 & 6.9 & 0.65 & 0.14 & $<$ & 0.03 & 0.11 & 0.012 & 46 & 8.2 & 2.5 & 3.2 \\
\hline & Tap slag, mean $(\mathrm{n}=10)$ & 26 & 0.38 & 7.6 & 52 & 1.8 & 1.7 & 8.5 & 0.98 & 0.20 & $<$ & 0.03 & 0.11 & 0.012 & 37 & 12 & 4.0 & 3.1 \\
\hline
\end{tabular}

${ }^{1}$ Main elements are main components normalized to $100 \%$ and calculated to elements.

S.D., standard deviation; <, below detection limit. 
the experiments compare. The further calculations will not recalculate the mass balances of the experiments, but of the two types of slag (tap slag and furnace slag) formed in it. So it will be possible to interpret the meaning of tap slag and furnace slag in these experiments.

All elements in the chemical composition of the materials studied, with the exception of the trace elements, are expressed as oxide components according to geochemical studies (Table 2). In a second step the analyses are normalized to $100 \%$ and the major components of ferric oxide $\left(\mathrm{Fe}_{2} \mathrm{O}_{3}\right)$, silica $\left(\mathrm{SiO}_{2}\right)$ and alumina $\left(\mathrm{Al}_{2} \mathrm{O}_{3}\right)$ are recalculated to elements for later calculations. The mean of the unroasted ore is based on nine analyses on single rock fragments with a maximum of morphological variations between each other. The mean of the roasted ore is based on three analyses on several, similar rock fragments.

The major component of the ore is ferric oxide $\left(\mathrm{Fe}_{2} \mathrm{O}_{3}\right)$; minor components are silica $\left(\mathrm{SiO}_{2}\right)$ and calcium oxide $(\mathrm{CaO})$, followed by manganese oxide $(\mathrm{MnO})$. The ore is poor in alumina $\left(\mathrm{Al}_{2} \mathrm{O}_{3}\right)$ compared with other Swiss ores (pisolithic and oolithic ores). The most abundant trace element is barium (Ba). The ore shows no consistent $\mathrm{Si} / \mathrm{Al}$ ratio, as it varies between 3 and 20 .

In the bloomery smelting process of the major compounds only ferric oxide, a part of $\mathrm{P}_{2} \mathrm{O}_{5}$ and the siderophile trace elements $\mathrm{Ni}, \mathrm{Co}, \mathrm{Cu}$ and $\mathrm{As}$ (see Table 5) are reduced, while all other components present in the ore contribute to slag formation. The sulphur present in the ore escapes to the atmosphere during reduction, because it was not found in the slag. Also a part of barium has disappeared.

Iron is the major element in the slag composition (Table 2). In general the slag contains little $\mathrm{MnO}$, but is rich in $\mathrm{SiO}_{2}$ and $\mathrm{CaO}$ like the ore. The enrichment is higher for three components: for $\mathrm{Al}_{2} \mathrm{O}_{3}$ and $\mathrm{TiO}_{2}$ it is between six and nine, and for $\mathrm{K}_{2} \mathrm{O}$ it is between 30 and 50 . The only material that could have provided further $\mathrm{Al}_{2} \mathrm{O}_{3}$ and $\mathrm{TiO}_{2}$ in the slag was the furnace lining, while the source for potassium was most likely the ash (main components $\mathrm{CaO}$ and $\mathrm{K}_{2} \mathrm{O}$ ). The slag has a more consistent $\mathrm{Si} / \mathrm{Al}$ ratio, between 1.8 and 5.3 (mean 3.2), than the ore. The reason for this behaviour is the smelting of the heterogeneous ore during the reduction process to a liquid and a more homogeneous slag. The slag analyses show a systematic difference between the compositions of furnace slag and tap slag, with the exception of Experiment 5. Tap slag was poorer in iron and more enriched in all other components than furnace slag.

A considerable amount of alumina must be added to the ore to achieve the tap slag and furnace slag $\mathrm{Si} / \mathrm{Al}$ ratio. This alumina is present in the furnace lining. Two furnace lining compositions are given in Table 2, one belonging to Experiment 2 with a Si/Al ratio of 1.6 (mean) and a second belonging to Experiment 5 with a $\mathrm{Si} / \mathrm{Al}$ ratio of 4.8. The differences can be explained by the use of two different clays making part of the furnace lining mixed from sand and clay. In Experiments 1 and 2 only a furnace lining from the first type was used. From Experiment 3 onwards, repairs of the furnace chamber were performed with a clay/sand-mixture of the second type. Because the $\mathrm{Si} / \mathrm{Al}$ ratio (4.8) of the second furnace lining type is higher than that in the slag of Experiments 4 and 5, it can be ruled out that this furnace lining is the single input of alumina to the slag composition. It could eventually work in Experiment 3, where the $\mathrm{Si} / \mathrm{Al}$ ratio of the slag varies between 4.9 and 5.3. The consequence is that the second furnace lining type has to be excluded from further consideration. It is not typical for the furnace lining involved in Experiments 3 to 5, which would probably be a mixture of both types. As a result, only the composition of the slag and furnace lining from Experiments 1 and 2 can be used for the recalculation of the mass balance and yield.

The first calculations of the mass balance are based on the mean composition of the roasted ore, on the mean composition of tap slag, furnace slag and furnace lining of Experiments 1 and 2 (Table 3). The ash composition is chosen as an example from a modern charcoal ash 
Table 3 Mass balances based on the mean chemical composition of the roasted ore and the slag from Experiments 1 and 2, calculating the quantity of materials involved and produced (starting weight: ore $30 \mathrm{~kg}$ )

Equation: $(a \times$ ore $)+(b \times$ furnace lining $)+(c \times$ ash $)=d \times \operatorname{slag}+e \times$ metal $\left(F e_{\text {total }}-F_{\text {slag }}\right)$

\begin{tabular}{|c|c|c|c|c|c|c|c|}
\hline Calculation 1 & Roasted ore & $\begin{array}{l}\text { Furnace } \\
\text { lining }\end{array}$ & Ash & Total & Difference & $\begin{array}{c}\text { Tap slag } \\
\text { (mean E1-2) }\end{array}$ & Metal \\
\hline $\mathrm{Si}^{\mathrm{a}}$ & 4.72 & 6.2 & 0.03 & 10.97 & & 10.97 & \\
\hline $\mathrm{Al}$ & 0.43 & 4.0 & 0.01 & 4.45 & & 4.45 & \\
\hline $\mathrm{Fe}$ & 55.82 & 5.6 & 0.04 & 61.48 & & 38.57 & 22.9 \\
\hline $\mathrm{Ti}$ & 0.02 & 0.2 & 0.001 & 0.27 & & 0.27 & \\
\hline Mn & 1.02 & 0.3 & 0.01 & 1.33 & - & 1.99 & \\
\hline $\mathrm{Mg}$ & 0.30 & 0.1 & 0.07 & 0.51 & - & 0.74 & \\
\hline $\mathrm{Ca}$ & 4.30 & 0.7 & 0.43 & 5.43 & & 5.43 & \\
\hline K & 0.02 & 0.3 & 0.06 & 0.35 & - & 0.64 & \\
\hline $\mathrm{P}$ & 0.04 & 0.02 & 0.02 & 0.08 & & 0.08 & \\
\hline $\mathrm{Sr}$ & 0.02 & 0.005 & 0.002 & 0.030 & - & 0.035 & \\
\hline $\mathrm{Ba}$ & 0.20 & 0.02 & 0.001 & 0.22 & ++ & 0.13 & \\
\hline V & 0.01 & 0.01 & 0.00001 & 0.016 & + & 0.013 & \\
\hline Ratio Si/Al & 11 & 1.6 & 3.6 & 2.5 & & 2.5 & \\
\hline $\begin{array}{l}\text { Variables a-e } \\
\text { Factor } 1=30 \mathrm{~kg} / \mathrm{a}\end{array}$ & $\begin{array}{l}a=0.994 \\
30.2\end{array}$ & $\mathrm{~b}=0.313$ & $\mathrm{c}=0.01$ & & & $d=1$ & $\mathrm{e}=0.229$ \\
\hline $\mathrm{kg}($ variables $\times$ Factor 1$)$ & 30.0 & 9.5 & 0.3 & & & 30.2 & 6.9 \\
\hline Calculation 2 & Roasted ore & $\begin{array}{l}\text { Furnace } \\
\text { lining }\end{array}$ & Ash & Total & Difference & $\begin{array}{l}\text { Furnace slag } \\
(\text { mean E1-2) }\end{array}$ & Metal \\
\hline $\mathrm{Si}$ & 2.52 & 4.07 & 0.10 & 6.69 & & 6.69 & \\
\hline $\mathrm{Al}$ & 0.23 & 2.62 & 0.03 & 2.88 & & 2.88 & \\
\hline $\mathrm{Fe}$ & 29.77 & 3.77 & 0.11 & 33.65 & & 49.29 & -15.6 \\
\hline $\mathrm{Ti}$ & 0.01 & 0.16 & 0.00 & 0.18 & & 0.18 & \\
\hline Mn & 0.54 & 0.20 & 0.03 & 0.78 & - & 1.60 & \\
\hline $\mathrm{Mg}$ & 0.16 & 0.09 & 0.21 & 0.46 & & 0.49 & \\
\hline $\mathrm{Ca}$ & 2.29 & 0.47 & 1.29 & 4.05 & & 4.17 & \\
\hline K & 0.01 & 0.18 & 0.19 & 0.38 & & 0.39 & \\
\hline $\mathrm{P}$ & 0.02 & 0.01 & 0.07 & 0.10 & + & 0.05 & \\
\hline $\mathrm{Sr}$ & 0.01 & 0.003 & 0.01 & 0.02 & & 0.03 & \\
\hline $\mathrm{Ba}$ & 0.11 & 0.01 & 0.004 & 0.12 & & 0.12 & \\
\hline V & 0.004 & 0.01 & 0.00004 & 0.01 & & 0.01 & \\
\hline $\mathrm{Si} / \mathrm{Al}$ & 11 & 1.6 & 3.6 & 2.3 & & 2.3 & \\
\hline $\begin{array}{l}\text { Variables a-e } \\
\text { Factor } 1=30 \mathrm{~kg} / \mathrm{a}\end{array}$ & $\begin{array}{l}a=0.53 \\
56.6\end{array}$ & $\mathrm{~b}=0.21$ & $c=0.03$ & & & $\mathrm{~d}=1$ & $\mathrm{e} \neq$ \\
\hline $\mathrm{kg}($ Variables $\times$ Factor 1$)$ & 30 & 11.9 & 1.7 & & & 56.6 & - \\
\hline
\end{tabular}

a The values shown are based on the analyses in Table 2, normalized to 100, calculated to elements and multiplied by the variables $\mathrm{a}-\mathrm{c} ; \mathrm{d}=1$, while $\mathrm{e}=$ iron amount $/ 100$. 
produced in other experiments (Serneels 2002). In a first stage the relative quantities of the three materials, ore, furnace lining and ash were calculated in a way that the sum of their elemental composition ( $\mathrm{Si}, \mathrm{Al}, \mathrm{Fe}$ ) matches the composition of the slag. For this condition to be fulfilled the variables $\mathrm{a}-\mathrm{c}$ ( $\mathrm{a}$ for ore, $\mathrm{b}$ for furnace lining, $\mathrm{c}$ for ash) were defined to reach the slag composition $(d=1)$. Then the other elements were included to check on the quality of the match. If this resulted in a poor match, the process was repeated in an iterative manner to achieve the best possible fit. In a second step the quantities of materials involved in the process were calculated based on $30 \mathrm{~kg}$ of ore used in experiments. So in Calculation 1 the $30 \mathrm{~kg}$ of ore was divided by 0.994 (variable a) resulting in 30.2 (factor 1). As a result in Calculation 1 concerning the tap slag, $9.5 \mathrm{~kg}$ of furnace lining and $0.3 \mathrm{~kg}$ of ash must have been added to $30 \mathrm{~kg}$ ore to reach the composition of the slag, producing $30.2 \mathrm{~kg}$ of slag and $6.9 \mathrm{~kg}$ of iron metal. Calculation 2 concerning the furnace slag could not be solved, as there was not enough iron in the ore to form slag and the metal. But was the iron content the reason why there was no solution of this calculation? The reason is a different one; the high $\mathrm{Si} / \mathrm{Al}$ ratio of the ore makes it necessary that a large amount of furnace lining is consumed in the process to form a slag with a low $\mathrm{Si} / \mathrm{Al}$ ratio.

Calculations 1 and 2, based on the mean composition of roasted ore, produce inconsistent mass balances. The calculations result in a weight of the products being over $37 \mathrm{~kg}$. The experiments have shown that the products weighed $30 \mathrm{~kg}$ or less (Table 1). A new series of experiments started in 2007 confirm this result. In addition the loss of 10 to $12 \mathrm{~kg}$ of furnace lining would have resulted in more extensive damage to the furnace chamber than was observed.

As a consequence, a roasted ore sample with a lower $\mathrm{Si} / \mathrm{Al}$ ratio (GON-C, Table 2$)$ was chosen in Calculations 3 and 4 (Table 4). It also has a slightly lower Fe content (54\%) than the mean of the roasted ore. The composition of the total and the mean of the tap slag and furnace slag in Table 4 varies more in the $\mathrm{Mn}, \mathrm{Mg}, \mathrm{Ca}, \mathrm{Sr}$ and $\mathrm{Ba}$ content, than was the case for Calculations 1 and 2. This is due to the high content of these elements in the chosen ore sample, all of them higher than in the mean ore compositions (Table 2). But the mass balances of these calculations are nearer to the experimental results than Calculations 1 and 2. The products weigh between 27 and $32 \mathrm{~kg}$ compared to 18 to $28 \mathrm{~kg}$ in the experiments (Table 1). As probably not all material was collected, especially not the unreduced ore, it can be said that the results look similar. Recalculating Experiment 1 based on the given slag quantities, about $3.6 \mathrm{~kg}$ metal should have been formed, whereas $3 \mathrm{~kg}$ was estimated. As the larger metal parts always adhered to the slag, the real metal weight is a rough estimate and could be higher.

Calculations 3 and 4 clearly show that by forming tap slag 4.2 times more metal is reduced than by building furnace slag. The mass balances of the collected materials (Table 1) also indicate that the formation of tap slag in the experiments is connected with the yield of the iron formation: the more tap slag is formed, the more iron is obtained. In contrast, the forming of furnace slag only allows the minimal formation of iron.

In Calculation $3,10.8 \mathrm{~kg}$ of metal forms the bloom and $6.2 \mathrm{~kg}$ of iron are involved in slag forming (weight of produced slag $16.1 \mathrm{~kg}$, Fe content $38.57 \%$ ). This results in a yield of $67 \%$, nearly identical with the optimum yield for the roasted ore. As a consequence the optimum yield must be seen as a valid method to predict the applied maximum yield based on calculations. But in experimental reality it will never happen that all the ore is reduced to slag.

The following conclusions can be drawn from the five experiments:

- the hematite ore from the Gonzen Mountains consumes furnace lining as a source of alumina for slag production; 
Table 4 Mass balances based on chemical composition of the single roasted ore GON-C and the slag from Experiments 1 and 2, calculating the quantity of materials involved and produced (starting weight: ore $30 \mathrm{~kg}$ )

Equation: $(a \times$ ore $)+(b \times$ furnace lining $)+(c \times$ ash $)=d \times \operatorname{slag}+e \times$ metal $\left(F e_{\text {total }}-F e_{\text {slag }}\right)$

\begin{tabular}{|c|c|c|c|c|c|c|c|}
\hline Calculation 3 & GON-C & $\begin{array}{c}\text { Furnace } \\
\text { lining }\end{array}$ & Ash & Total & Difference & $\begin{array}{c}\text { Tap slag } \\
\text { (mean E1-2) }\end{array}$ & Metal \\
\hline $\mathrm{Si}^{\mathrm{a}}$ & 5.59 & 5.38 & NONE & 10.97 & & 10.97 & \\
\hline $\mathrm{Al}$ & 0.98 & 3.47 & & 4.45 & & 4.45 & \\
\hline $\mathrm{Fe}$ & 100.60 & 4.87 & & 105.47 & & 38.57 & 66.9 \\
\hline $\mathrm{Ti}$ & 0.06 & 0.21 & & 0.27 & & 0.27 & \\
\hline Mn & 5.50 & 0.26 & & 5.76 & ++ & 1.99 & \\
\hline $\mathrm{Mg}$ & 1.13 & 0.12 & & 1.24 & + & 0.74 & \\
\hline $\mathrm{Ca}$ & 12.28 & 0.60 & & 12.89 & ++ & 5.43 & \\
\hline $\mathrm{K}$ & $<$ & 0.24 & & 0.24 & - & 0.64 & \\
\hline $\mathrm{P}$ & 0.06 & 0.01 & & 0.07 & & 0.08 & \\
\hline $\mathrm{Sr}$ & 0.07 & 0.004 & & 0.08 & + & 0.04 & \\
\hline $\mathrm{Ba}$ & 0.69 & 0.02 & & 0.71 & +++ & 0.13 & \\
\hline $\mathrm{V}$ & 0.02 & 0.01 & & 0.02 & & 0.01 & \\
\hline Ratio Si/Al & 5.7 & 1.6 & & 2.5 & & 2.5 & \\
\hline Variables & $\mathrm{a}=1.86$ & $\mathrm{~b}=0.271$ & & & & $\mathrm{~d}=1$ & $\mathrm{e}=0.669$ \\
\hline Factor $1=30 \mathrm{~kg} / \mathrm{a}$ & 16.13 & & & & & & \\
\hline $\mathrm{kg}($ Variables $\times$ Factor 1$)$ & 30 & 4.4 & & & & 16.1 & 10.8 \\
\hline Calculation 4 & GON-C & $\begin{array}{c}\text { Furnace } \\
\text { lining }\end{array}$ & Ash & Total & Difference & $\begin{array}{c}\text { Furnace slag } \\
\text { (mean E1-2) }\end{array}$ & Metal \\
\hline $\mathrm{Si}$ & 3.05 & 3.64 & NONE & 6.69 & & 6.69 & \\
\hline $\mathrm{Al}$ & 0.53 & 2.35 & & 2.88 & & 2.88 & \\
\hline $\mathrm{Fe}$ & 54.90 & 3.30 & & 58.20 & & 49.29 & 8.9 \\
\hline $\mathrm{Ti}$ & 0.03 & 0.14 & & 0.17 & & 0.18 & \\
\hline $\mathrm{Mn}$ & 3.00 & 0.18 & & 3.18 & ++ & 1.60 & \\
\hline $\mathrm{Mg}$ & 0.61 & 0.08 & & 0.69 & + & 0.49 & \\
\hline $\mathrm{Ca}$ & 6.70 & 0.41 & & 7.11 & ++ & 4.17 & \\
\hline K & $<$ & 0.16 & & 0.16 & - & 0.39 & \\
\hline $\mathrm{P}$ & 0.03 & 0.01 & & 0.04 & & 0.05 & \\
\hline $\mathrm{Sr}$ & 0.04 & 0.003 & & 0.04 & & 0.03 & \\
\hline $\mathrm{Ba}$ & 0.38 & 0.01 & & 0.39 & ++ & 0.12 & \\
\hline $\mathrm{V}$ & 0.01 & 0.006 & & 0.015 & & 0.014 & \\
\hline $\mathrm{Si} / \mathrm{Al}$ & 5.7 & 1.6 & & 2.3 & & 2.3 & \\
\hline Variables & $\mathrm{a}=1.015$ & $\mathrm{~b}=0.1835$ & & & & $\mathrm{~d}=1$ & $\mathrm{e}=0.089$ \\
\hline Factor $1=30 \mathrm{~kg} / \mathrm{a}$ & 29.56 & & & & & & \\
\hline $\mathrm{kg}($ Variables $\times$ Factor 1$)$ & 30 & 5.4 & & & & 29.56 & 2.6 \\
\hline
\end{tabular}

a The values shown are based on the analyses in Table 2, normalized to 100, calculated to elements and multiplied by the variables $\mathrm{a}-\mathrm{c} ; \mathrm{d}=1$, while $\mathrm{e}=$ iron amount $/ 100$. 
- the chemical composition of the ore used in experiments is near to the mean composition of the roasted ore, but with a lower $\mathrm{Si} / \mathrm{Al}$ ratio (example GON-C 5.7);

- if the ore has a higher $\mathrm{Si} / \mathrm{Al}$ ratio, a lot of furnace lining will be consumed;

- the furnace slag allows only the formation of minimal quantities of iron metal;

- the tap slag has nearly the same maximum yield (67\%) as the optimum yield of the ore;

- the experimental bloomery smelting yield of Gonzen hematite is below $67 \%$.

\section{EXPERIMENTS COMPARED TO ARCHAEOLOGICAL BACKGROUND}

What have the slags in these experiments in common with an archaeological iron smelting slag? We know very little about the bloomery smelting of the hematite ore from the Gonzen Mountains. The only evidence is the find of two poorly described furnaces at the end of the 19th century in Heiligkreuz, near the Gonzen Mountains (Epprecht 1986). A slag from this place, in the collection of the St. Gall museum, was dated by radiocarbon to early medieval times, while charcoal samples from the same context are 500 years younger. The slag has a manganese content of $9 \%$, which relates it clearly to the Gonzen ore as no other ores in the region have a major manganese content. Another slag from Castels nearby has suggested the smelting of Gonzen ore in Late Iron Age or early Roman Times. The slag is described as tap slag containing inclusions of Gonzen ore (Epprecht 1986). This dataset is too poor to really understand when, and in what technical context, bloomery iron smelting of Gonzen ore was carried out. Given the lack of local archaeological evidence, the experimental slag is compared to the well-known early medieval bloomery smelting slag in Switzerland (Eschenlohr and Serneels 1991, Serneels 1993, Serneels and Beck 1998, Beck and Senn 2000, Eschenlohr 2001). On every bloomery smelting site, tap slag is found, but furnace slag is rare. Archaeological and experimental tap slag have similar iron contents. But, in experiments, the archaeological slag from inside the furnace was found to be poorer in iron than the furnace slag. For this reason, the forming of iron-rich furnace slag must be explained by the poor reduction of ore during experiments. Only in Experiment 5, did tap slag and furnace slag have similar chemical compositions. Also this experiment produced the most metallic iron, which suggests that Experiment 5 was the nearest to archaeological reality.

The reaction between ore and furnace lining is well known in bloomery smelting site studies. The calculations above show that it has a nearly parallel influence on the yield, on the quantity of slag formed and on the quantity of furnace lining involved. As an example, in Calculations 1 and 3, respectively, 30.2 and $16.1 \mathrm{~kg}$ slag were produced (Tables 3 and 4), while the metal quantity varied between $6.9 \mathrm{~kg}$ and $10.8 \mathrm{~kg}$ and the furnace lining involved between $4.4 \mathrm{~kg}$ and $9.5 \mathrm{~kg}$. So the slag quantity decreased by $43 \%$, while the metal production increased by $57 \%$. The contribution of furnace lining decreased at the same time by $54 \%$. But must a tap slag increase in alumina compared with the ore? Is the only possible solution for producing slag the reduction of the ore and the reaction with the furnace lining or tuyere? Again a comparison with early medieval smelting sites can give answers. A very similar ore to hematite is the magnetite from Mont Chemin, Switzerland (Serneels and Beck 1998). The magnetite is also poor in alumina, with a $\mathrm{Si} / \mathrm{Al}$ ratio varying between 5 and 30 . The reduced ore is assumed to have a ratio of 8 ; the tap slag has one of 6 , while the furnace lining has one of 4 . In the mass balance of the magnetite ore, calculated on $30 \mathrm{~kg}$ ore, $2.6 \mathrm{~kg}$ furnace lining was needed to form the slag. This example is similar to Calculation 3 in Table 4 . The situation is different for the yield and mass balance of the siderolithic ore. Its yield is only about $30 \%$, because of the high alumina content of the ore. In the mass balance $3 \mathrm{~kg}$ furnace lining react 
Table 5 Trace elements in metal produced from hematite ore from Gonzen SG, Switzerland

\begin{tabular}{|c|c|c|c|c|c|c|c|}
\hline \multirow{2}{*}{ Sample } & $M n$ & $P$ & Co & $N i$ & $\mathrm{Cu}$ & As & \multirow{2}{*}{$\begin{array}{c}\mathrm{Ni} / \mathrm{Co} \\
\text { ratio }\end{array}$} \\
\hline & \multicolumn{6}{|c|}{$m g / k g$} & \\
\hline GON1, ore ${ }^{\mathrm{a}}$ & n. d. & n. d. & 20 & 47 & 7 & 46 & 2.4 \\
\hline GON2, ore & n. d. & n. d. & 9 & 59 & 16 & 31 & 6.4 \\
\hline GON3, ore & n. d. & n. d. & 8 & 36 & 12 & 34 & 4 \\
\hline GON4, ore & n. d. & n. d. & 25 & 59 & 14 & 66 & 2.4 \\
\hline GON5, ore & n. d. & n. d. & 31 & 60 & 9 & 52 & 1.9 \\
\hline GON6, ore & n. d. & n. d. & 2 & 28 & 6 & 28 & 10 \\
\hline GON7, ore & n. d. & n. d. & 20 & 66 & 14 & 51 & 3.3 \\
\hline GON8, ore & n. d. & n. d. & 5 & 41 & 9 & 32 & 9.1 \\
\hline Mean & $10200^{\mathrm{d}}$ & $400^{\mathrm{d}}$ & 15 & 50 & 11 & 43 & 4.9 \\
\hline S.D. & a & - & 10 & 14 & 4 & 13 & 3 \\
\hline Bloom, exp. $2^{\mathrm{b}}$, median $^{\mathrm{e}}$ & 100 & 40 & 90 & 400 & 70 & 400 & 4.6 \\
\hline Bloom, exp. 3 , median & 100 & 30 & 40 & 200 & 50 & 200 & 4.4 \\
\hline Bloom, exp. 4, median & 400 & 20 & 50 & 300 & 260 & 100 & 5.1 \\
\hline Bloom, exp. 5, median & 20 & 400 & 60 & 330 & 100 & 470 & 5.9 \\
\hline Mean & 155 & 123 & 60 & 308 & 120 & 293 & 5.0 \\
\hline S.D. & 168 & 185 & 22 & 83 & 96 & 172 & 0.7 \\
\hline Billet B, forged from bloom, exp. 5, median & 200 & 70 & 60 & 180 & 400 & 200 & 3 \\
\hline Billet $\mathrm{C}$, forged from bloom, exp. 5 , median & 100 & $<$ & 70 & 340 & 80 & 340 & 4.6 \\
\hline Metal inclusion in $\mathrm{PCB}^{\mathrm{c}}$ & 100 & 200 & 100 & 300 & 170 & 200 & 2.7 \\
\hline
\end{tabular}

\footnotetext{
${ }^{\text {a }}$ Ore analysed by ICP-MS.

${ }^{\mathrm{b}}$ Metal analysed by LA-ICP-MS.

${ }^{\mathrm{c}} \mathrm{PCB}$, plano-convex hearth bottom slag.

${ }^{\mathrm{d}}$ Calculated from roasted ore.

e Median based on five single analyses.
}

with $30 \mathrm{~kg}$ ore to produce the tap slag (Eschenlohr and Serneels 1991). The Si/Al ratios of the materials involved are very different: 0.7 in the siderolithic ore, 3.7 in the furnace lining and 1.1 in the tap slag. Here the slag is enriched in $\mathrm{Si}$ and not in $\mathrm{Al}$ as is the case in the examples discussed before. But the amounts of furnace lining involved in the reduction process are similar in all examples. The reaction between furnace lining or tuyere and ore to form smelting slag is not restricted to early medieval Switzerland. It seems to be as old as bloomery smelting. A recent publication about iron smelting in the 1st millennium $\mathrm{BC}$ in Rwanda and Burundi (Urewe Culture), Africa, showed that in this region a similar effect occurred (Craddock et al. 2007) and it also occurred in the ethnographically documented record. It is also reported from Tell Hammeh in Israel in the 10th century BC (Veldhuijzen and Rehren 2007). In Tell Hammeh $5.7 \mathrm{~kg}$ of furnace lining participates in the formation of slag by the reduction of $30 \mathrm{~kg}$ ore, while no quantification is available from the Urewe Culture.

A further result of our experiments is the chemical composition of the metal (Table 5). The elements nickel, cobalt, copper and arsenic are enriched in the metal, while phosphorus is partially enriched, and manganese only to a minor degree. Metal composition from these experiments give archaeologists a basis upon which to decide whether iron artefacts are produced 
from the iron ore of Gonzen Mountains. The slag composition can only be used with caution. From the scarce archaeological data we know that the archaeological slag can contain about 9\% manganese, while the experimental slag contains only $1.8 \%$ manganese (mean Table 2). This means that depending on where in the deposit ore was used, major variations in manganese content can occur. A further reason that will influence the slag composition is the composition of the furnace lining. It is unlikely that a clay as rich in alumina as the experimental one was used in the archaeological context. The clay used in the experiments is typical for the siderolithic context of the Jura Mountains in Switzerland. It is mined in Lohn, canton of Schaffhausen. Siderolithic clay does not occur in the Alpine context of the Gonzen Mountains. So a clay poorer in alumina was used in reality. This will have the effect of raising the $\mathrm{Si} / \mathrm{Al}$ ratio in the slag. As an example, the experiments could also be affected with a furnace lining similar to Mont Chemin, producing tap slag with a $\mathrm{Si} / \mathrm{Al}$ ratio similar to that from Mont Chemin.

The metal composition of experimental iron in Table 5 was used to check if the iron artefacts from the late Iron Age ritual site of Wartau-Ochsenberg in the same valley as the Gonzen Mountains (Senn Bischofberger 2005) were produced with Gonzen ore. The result was not unexpected: none of them were produced with the local ore. The artefacts had a higher content of all elements and a lower $\mathrm{Ni} / \mathrm{Co}$ ratio. For a more reliable identification of the origin of iron artefacts, Schwab et al. (2006) proposed using the lead isotope ratio in addition to metal and slag chemical composition. This is necessary because in the same ore family the chemical composition can be very similar. For this reason it is quite difficult to localize the geographical origin of a metal only by its chemical composition.

\section{CONCLUSIONS}

The analytical instruments did enable us to control the influence of experimental parameters by varying only one parameter at a time, namely, the air supply. The air supply has considerably influenced the yield of the iron reduction process. The measured slight overpressure in the furnace centre, necessary to reach the high temperature, confirmed that the bellows dimensions were adequate. It could be demonstrated that the amount of tap slag formed by smelting is a direct reflection of the efficiency of the reduction process. It is therefore an indicator for the quantity of iron metal produced. For an ideal bloomery smelting with a high yield, the production of tap slag should be increased. This may be done with an increase of process temperature to $1100^{\circ}$ and $1200^{\circ} \mathrm{C}$, in application of the theoretical model, the ternary diagram presenting liquidus temperatures for the system $\mathrm{SiO}_{2}-\mathrm{Al}_{2} \mathrm{O}_{3}-\mathrm{FeO}$ or fayalite-wustite-hercynite (Verein Deutscher Eisenhüttenleute 1995).

The calculations show a good parallel between theory, experimentation and archaeology. Theoretical and applied models fit well. Future research should concentrate on temperature and oxygen partial pressure to model the process more accurately.

\section{ACKNOWLEDGEMENTS}

For the ore we thank the Eisenbergwerk Gonzen AG for helping us to bring about one tonne of ore out of the Wolfslochstollen. For their help during experiments we thank the smiths Mathias Hotz, Klaus Kriening, Christopher Halbsguth, the carpenter Rolf Bischofberger and the archaeologists Stefan Schreyer and Sabine Bolliger, also Paul Merluzzo from the 'Laboratoire d'archéologie des métaux' in Nancy, France for doing the bloom smithing experiments. For teaching us mol calculation, thanks are due to Norbert Heeb. 


\section{REFERENCES}

Beck, B., and Senn, M., 2000, Zur Eisenverhüttung im Durachtal, in Berslingen-ein verschwundenes Dorf bei Schaffhausen (K. Bänteli, M. Höneisen and K. Zubler), 241-69, Schaffhauser Archäologie 3, Schaffhausen.

Craddock, P., Freestone, I., Middleton, A., and Van Grunderbeek, M.-C., 2007, Early Iron Age iron-smelting debris from Rwanda and Burundi, East Africa, Historical Metallurgy, 41, 1-14.

Crew, P., 1994, Currency bars in Great Britain, typology and function, in La sidérurgie ancienne de l'Est de la France dans son contexte européen. Actes du colloque de Besançon 1993 (ed. M. Mangin), 345-50, Annales litteraires de l'Université de Besançon, 536, Paris.

Crew, P., and Charlton, M., 2007, The anatomy of a furnace . . . and some of its ramifications, in Metals and mines, studies in archaeometallurgy (eds. S. La Niece, D. Hook and P. Craddock), 219-25, Archetype Publications Ltd, London.

Devos, W., Senn-Luder, M., Moor, C., and Salter, C., 2000, Laser ablation inductively coupled plasma mass spectrometry (LA-ICP-MS) for spatially resolved trace analysis of early-medieval archaeological iron finds, Fresenius, Journal of Analytical Chemistry, 366, 873-80.

Epprecht, W., 1986, Neues vom alten Bergbau am Gonzen (Sargans), Minaria Helvetica, 6a, 18-28.

Eschenlohr, L., 2001, Recherches archéologique sur le district sidérurgique du Jura centrale suisse, Cahiers d'archéologie romande No. 88, Lausanne.

Eschenlohr, L., and Serneels, V., 1991, Les bas fourneaux mérovingiens de Boécourt, Les Boulies (JU/Suisse), Cahier d'archéologie jurassienne 3, Porrentruy.

Eschenlohr, L., Friedli, V., Robert-Charrue Linder, C., and Senn, M., 2007, Develier-Courtételle, un habitat rural mérovingien. 2. Métallurgie du fer et mobilier métallique, Cahier d'archéologie jurassienne 14, Porrentruy.

Pfeifer, H.-R., Oberhänsli, H., and Epprecht, W., 1988, Geochemical evidence for a synsedimentary hydrothermal origin of Jurassic iron-manganese deposits at Gonzen (Sargans, helvetic Alps, Switzerland), Marine Geology, 84, $257-72$.

Schwab, R., Heger, D., Höppner, B., and Pernicka, E., 2006, The provenance of iron artefacts from Manching: a multi-technique approach, Archaeometry, 48, 433-52.

Senn, M., Lienemann, P., and Bührer, T., 2001, Archäologische Eisenverhüttung im Experiment, Messungen von Reaktionsparametern und Reaktionsprodukten, Zeitschrift für Archäologie und Kunstgeschichte, 58, 81-8.

Senn Bischofberger, M., 2005, Das Schmiedehandwerk im nordalpinen Raum von der Eisenzeit bis ins frühe Mittelalter, Internationale Archäologie, Naturwissenschaft und Technologie, vol. 5, Rahden/Westf.

Serneels, V. 1993, Archéométrie des scories de fer. Recherches sur la sidérurgie ancienne en Suisse occidentale, Cahiers d'archéologie romande No. 61, Lausanne.

Serneels, V., 2002, Analyses chimiques des matières premières et produits de l'opération de réductions dans le four basque d'Agorregi, in Agorregiko burdinola eta errotak (Aia, Gipuzkoa), (ed. M. M. Urteaga), 93-121, arkeologia 3, Departamento de Cultura, Euskera, Juventud y Deportes, San Sebastian.

Serneels, V., and Beck, B., 1998, Les scories du Mont Chemin et l'utilisation de la magnétite pour fabriquer du fer par la méthode directe de réduction, Minaria Helvetica, 18b, 43-65.

Veldhuijzen, H. A., and Rehren, T., 2007, Slags and the city: early iron production at Tell Hammeh, Jordan, and Tel Beth-Shemesh, Israel, in Metals and mines, studies in archaeometallurgy (eds. S. La Niece, D. Hook, and P. Craddock), 189-201, Archetype Publications Ltd, London.

Verein Deutscher Eisenhüttenleute, 1995, Slag Atlas, 2nd edition, Verein Deutscher Eisenhüttenleute, Düsseldorf. 